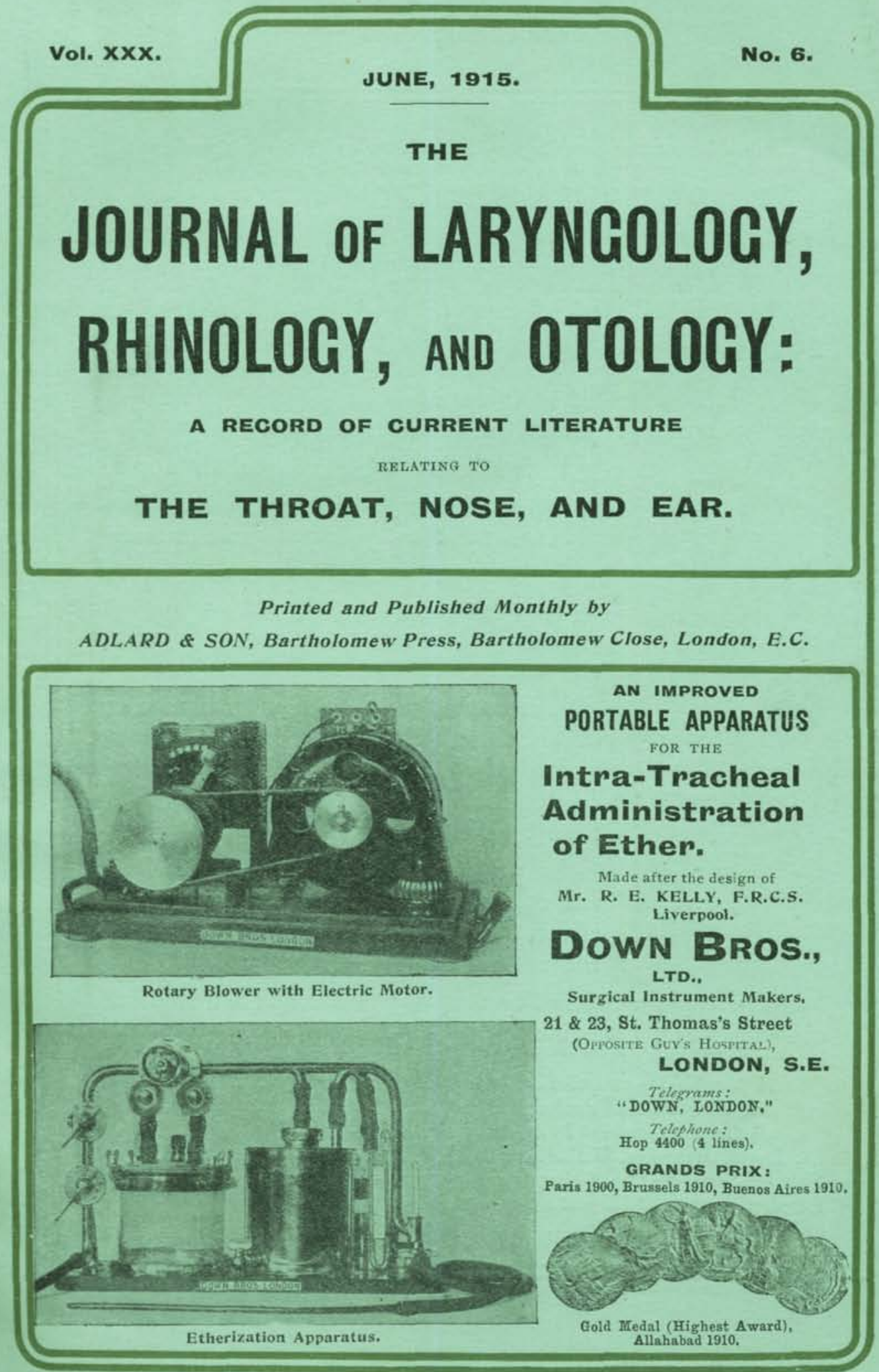

Prepaid Annual Subscription, fi (5 dollars) post free. Single Copies, Two Shillings. ENTERED AT STATIONERS' HALL. 
We have experimentally proved that Listerine is a powerful antiseptic, preventing the development of bacteria and decomposition of vegetable infusions.-British Medical Journal, May 3, 1890.

\section{IISTERINE ANTISEPTIC of known and definite power, prepared in a form convenient for immediate use.}

It is a saturated solution of boric acid, reinforced by the antiseptic properties of ozoniferous oils.

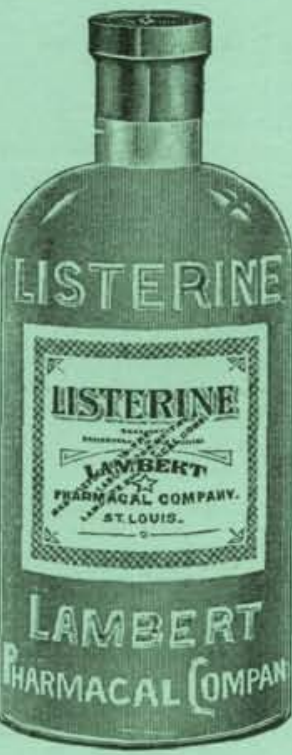

It is unirritating, even when applied to the most delicate tissue.

It does not coagulate serous albumen.

It is quite generally accepted as the standard antiseptic preparation for use where a poisonous or corrosive disinfectant can not be safely used.

It is particularly useful in the treatment of abnormal conditions of the mucosa, and admirably suited for a wash, gargle or douche in catarrhal conditions of the nose and throat.

In proper dilution, it may be freely and continuously used without prejudicial effect, either by injection or spray, in all the natural cavities of the body.

There is no possibility of poisonous effect through the absorption of Listerine

A pamphlet descriptive of the antiseptic, and indicating its utility in medical, surgical and dental practice, may be had upon application to the manufacturers, Lambert Pharmacal Co., Locust and Twenty-first Streets, St. Louis, Missouri, U.S.A., or to their British A gents, Messrs. S. Maw, Son \& Sons, 7-12, Aldersgate Street, London, Eng., but the best advertisement of Listerine is

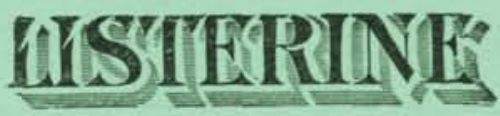




\section{THE JOURNAL OF LARYNGOLOGY, RHINOLOGY, AND OTOLOGY.}

Founded in 1887 ḅv MORELL MACKENZIE and NORRIS WOLFENDEN.

\section{A. GHE ATLE, F.R.C.8.} (Pres, Otol. Sect. Internat. Cong.)
DUNDAB GRANT, M.A., M.D., F.R.C.s.(London).
ALBERT A. GRAY, M.D. (Glasgow).
(Pres, Otol. Sect. R.8.M.) WILLIXI HILL, M.D. (London).

Pres. Laryng. Sect. R.s.M.)
OF THE EDITORIAL COMMITTEE :

J. MACINTYRE, M.B., C.M. (Glassow).

Sir W. MILLIGIN, M.D., M.Ch. (Tanchester). Sir StCLNIR THOHSON, M.D., F.R.C.8.(London). (Pres. Laryng. Sect. Internat. Cons.). LOGAN TURNER, M.D. (Edinburgh).

P. WATSON-WILLIA Ms, M.D. (Bristol).

MICLEOD YEARBLEY, F.R.C.8. (London).

EDITOR :

DAN MCKENZIE, M.D., F.R.C.B.E. (London),

To zehon all communications should be addressed.

WITH THE CO-OHERATION UF THE STAFF OF ABSTRACTORS:

Drs. J. Stoddart Barr(Glasgozw), H.S. Birkett (Montreal), Brady (Sydney, N.S.W. John Darling (Edinburgh), Donelan (London), Clayton Fox (London), J. S. Fraser (Edinburgh), Perry Goldsmith (Toronto), Thos. Guthrie (Liverpool), A. Hutchison (Brighton), J. D. Lithgow (Edinburgh), A. MCCal. (Bournemouth),

Chichele Nourse (London), W. G. Porter (Edinburgh),

Knowles Renshaw (Manchester), Archer Ryland (London),

I,indey Sewell (Manchester), Alex. R. Tweedie (Nottingham), C. E. West (London), G. Harold L. Whale (London), WRIGHT (Bristol), and WYLIE (London).

\section{AND THE ASSISTANCF OF}

Mr. George Badgerow (London), Drs. J. Barr (Glasgow), Hugo Frey (Vienna), Grazzi (Florence), Mindiemass HuNi (Liverpiol).

A. Brown Kelly (Glasgow), E. LAW (London), Massei (Naples)

D. Paterson (Cardiff), Urban Pritchard (London), F. A. Rose (London),

A. Sandford (Cork), Sendziak (Warsaz), H. Tilley (London),

Raymond Verel (Aberdeen), E. Waggett (London), R. Wiods (Dublin).

\section{CONTRIBUTORS TO THIS NUMBER.}

Dr. A. Logan Turner.

Mr. J. S. FRASER.

Mr. Macleod Yearsley.

DR. A. J. Brady.
DR. BIRKETT.

DR. ROGERS.

Dr. Price Brown.

Dr. D. R. Paterson.
Sir StClair Thomson.

Dr. WyatT Wingrave.

Mr. Thomas Guthrie.

\section{ITational $\underline{\mathbb{R e} \text { lief }} \underline{\mathrm{jfund} .}$}

To H.R.H. The Prince of IVales,

Buckingham Palace, London.

I beg to enclose $f \quad$ : $\quad$ s. $\quad$ d. as a donation to the

National Relief Fund.

Nanne

Address

The envelope containing this coupon need not be stamped. 


\section{CONTENTS.}

Special Article-

Reports for the Year 1914 from the Ear and Throat Department of the Royal Infirmary, Edinburgh. Part III.-Tuberculosis of the Middle-ear Cleft in Children : A Clinical and Pathological Study.A. Logan Turner and J. S. Fraser $\ldots$...

\section{Bocieties' Proceedings-}

Rotal Society of Medicing.-Otological Section.-Discussion on Tuberculosis of the Auditory Apparatus. Communications by Wrat't Wingrave, arthur Cheatle, W. Stuart-Low, C. E. West, E. D. Davis

Abstracts-

Pharynx.-A Hiding-place for Fish-bones in the Throat $\quad \ldots \quad \ldots \quad 258$

Nosk.-Variations of Sphenoidal Sinus Disease.-Accessory Nasal Sinus $\begin{array}{lllllllllll}\text { Suppuration } & \ldots & \ldots & \ldots & \ldots & . & \ldots & \ldots & \ldots & \ldots & \mathbf{2 5} 8\end{array}$

LARYNX. - Spindle-cell Sarcoma of the Larynx.-Intrinsic Cancer of the $\begin{array}{llllllllllll}\operatorname{Larynx} & \ldots & \ldots & \ldots & \ldots & \ldots & \ldots & \ldots & \ldots & \ldots & 259\end{array}$

EAR.-Further Remarks on the Use of Nitrate of Silver applied within the Mouth of the Eustachian Tube for the Relief of Tinnitus.Latent Mastoiditis complicated by Toxic and Irritative Cerebral Symptoms, accompanied by Blindness and a Streptococcæmia caused by Trauma; Operation; Recovery.-How the Patient can help himself in Cases of Chronic Catarrhal Otitis Media.-On the Cellular Reactions induced by Local Deposits of Cholesterin $\quad \ldots \quad 26$

Miscellaneous.- Tuberculosis of the Bronchial Glands and Lung Hilus : a Clinical and Radiographic Study.-Observations on the Treatment of Cancer and Sarcoma by Means of Pyraloxin, etc.

\section{Review-}

$\begin{array}{lllllllll}\text { The Tonsils. By Harky A. Barnes, M.D. } & \ldots & \ldots & \ldots & \ldots & \ldots & 262\end{array}$

$\begin{array}{llllllllllll}\text { Obituary } & \ldots & \ldots & \ldots & \ldots & \ldots & \ldots & \ldots & \ldots & \ldots & \ldots & \boldsymbol{2} 63\end{array}$

$\begin{array}{llllllllll}\text { Notes and Queries } & \ldots & \ldots & \ldots & \ldots & \ldots & \ldots & \ldots & \ldots & 2644\end{array}$ 


\section{Cerebro=spinal Meningitis .}

\section{MENINGOCOCCUS VACCINE}

for preventiveinoculation

Prepared from several strains of the Diplococcus intracellularis meningitidis (Weichselbaum) isolated during the present epidemic of cerebrospinal meningitis.

Supplied in sets of 2 bulbs (affording prophylactic treatment for one adult), also in bottles of 25 c.c. (sufficient for 16 adults).

\section{MENINGOCOCCUS VACCINE}

for use in treatment

Prepared from several strains of the Diplococcus intracellularis meningitidis (Weichselbaum) isolated during the present epidemic of cerebrospinal meningitis.

Issued in a dilution containing 25 million meningococci per c.c., and supplied in bulbs of I c.c., also in bottles of $25 \mathrm{c}, \mathrm{c}$.

\section{ANTIMENINGITIC SERUM}

for use in treatment

Obtained from the blood of horses which have been immunised to the Diplococcus intracellularis meningitidis (Weichselbaum).

The mortality from epidemic cerebro-spinal meningitis has been greatly reduced since the introduction of serum treatment.

Supplied in bulbs of 15 c.c.

Further particulars zeill be supplied on request by

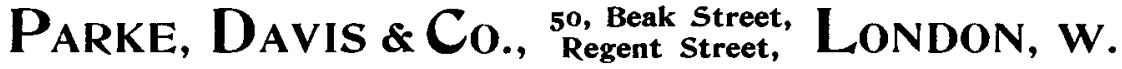
T'elegraphic and Cable Address : "Cascara, London." Telephones: Regent 3260 (six lines).

\section{Medical Temperance Review.}

Edited by H. J. PATERSON, M.B. QUARTERLY. Sixpence per Number net. ADLARD \& SON, BARTHOLOMEW CLOSE, LONDON, E.C.

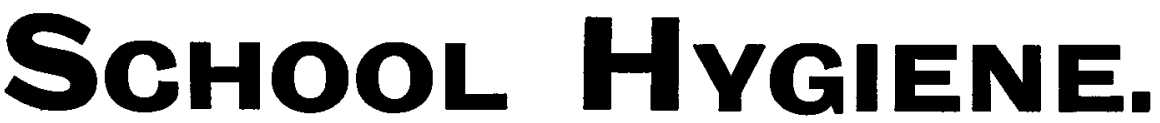

Published under the auspices of

The Medical Officers of Schools Association.

QUARTERLY. ANN. SUB. 4/6 post free.

ADlard \& SON, Bartholomew Close, London, e.C. 


\title{
HOSPITAL FOR
}

\section{DISEASES OF THE THROAT}

\section{GOLDEN SQUARE, LONDON, W.}

\author{
HONORARY MEDICAL STAFF. \\ Consulting Surgeons $\left\{\begin{array}{l}\text { MR. MARK HOVELL. } \\ \text { DR. LAMBERT LACK. }\end{array}\right.$
}

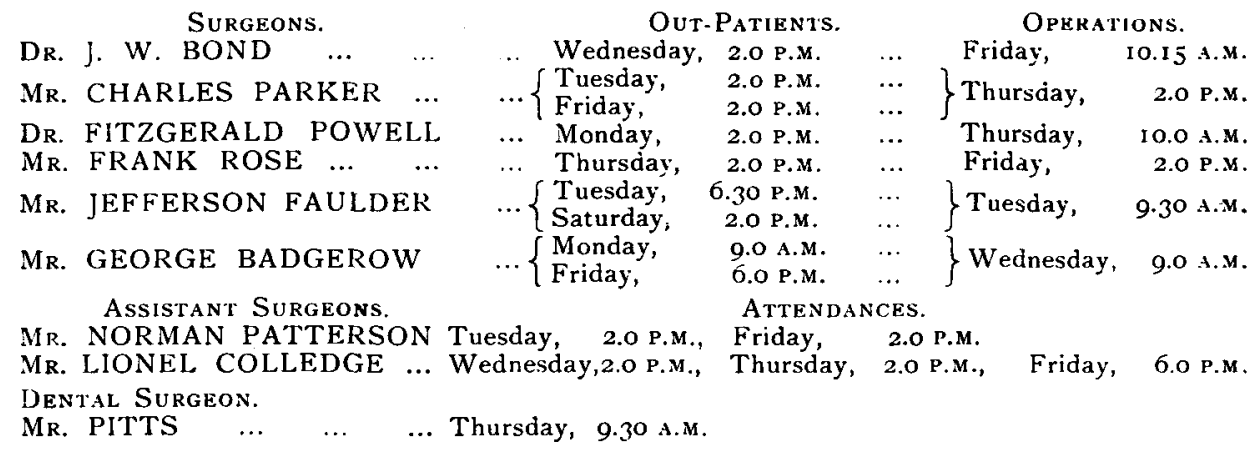

\section{CLINICAL INSTRUCTION.}

A Clinical Demonstration on the Diagnosis and 'Treatment of Selected Cases (Larynx, Nose, Ear) will be given each Monday at 5 p.m.

A Course in Surgical Anatomy and Physiology will be given each Thursday at 5 p.m. These Courses are free to Students of the Hospital. Others a fee of 2 guineas for each Course.

Practical Instruction in the Diagnosis and Treatment is given daily in the Out-patient Department from 2 to 5 p.m., on Tuesdays and Fridays from $6.3 \circ$ p.m. to 9 p.m., and Mondays at 9.30 a.m.

Major Operations are performed at io a.m. on Tuesciay, Wedinesday. Thursday, Friday, and Saturday, and Fridays at 2 p.m.

Minor Operations daily (Mondays excepted) at $9.3^{\circ} \mathrm{a} . \mathrm{m}$.

Operative Surgery Classes can be formed at any time on application.

Practice in Direct Laryngoscopy, Tracheoscopy, Bronchoscopy, and Esophagoscopy will be given to Students, to enable them to become familiar with the use and manipulation of the instruments.

Practitioners and Medical Students are admitted to the Practice of the Hospital at a fee of five guineas for three months, eight guineas for six months, or ten guineas for a Perpetual Studentship. Each course may commence at any date. special terms to men in actual practice who can only attend the hospital once or iwice a week.

The Hospital contains 60 beds for In-patients. There s also an Out-patient attendance of nearly 50,000 yeariy.

Gentlemen may enter to the practice of The Throat Hospital at any time, and on certain conditions eligible for appointment as Clinical Assistants, whose duty it is to Assist the Member of the Staff to whom they are appointed.

GEORGE W. BADGEROW, F.R.C.S., Hon. Med. Sec. 